\title{
Fäder i Sovjetryssland: Ideal, känslor och praktik
}

\author{
Helene Carlbäck ${ }^{\star}$
}

Södertörns högskola

\begin{abstract}
What makes a good father? Ideals and practices in late socialist Russia This article investigates fatherhood ideals and practices in late Soviet Russia, 1960-1989. For the theoretical basis, dominant ideals on masculinity and fatherhood have been derived from the rich but predominantly Western research literature of the past three decades. These are used as guiding tools in examining the research material for this study: the monthly magazine Semia i shkola. Zhurnal dlia roditelei (Family and School; Journal for Parents) and eleven in-depth interviews with men in Russia on their memories of fatherhood in the 1960s-1980s.

The research questions are: What did the ideal image of fatherhood look like in this period? What remembered practices do respondents communicate in interviews, and how do these relate to dominant public/official ideals of the time? Are there differences in the emphasis on various aspects of fatherhood ideals/practices between public discourses and the accounts given by these men? The interview narratives yield a multifaceted picture, with both coinciding and contradictory representations of the respondents' ideal images, on the one hand, and remembered practices, on the other. Possible explanations are then discussed. In conclusion, Soviet Russian fatherhood is tentatively contextualized within the framework of research results on Western fatherhood.
\end{abstract}

Keywords: Soviet Russia, men's life-stories, changing family models, fatherhood discourse \& practice, ideal images, gender roles

\section{Ett gott faderskap? Ideal och praktik i det sensocialistiska Ryssland}

Syftet med min studie är att lyfta fram offentliga/officiella idealbilder av faderskap under de sensocialistiska decennierna av den sovjetryska perioden. Hur såg idealbilden av det sovjetryska faderskapet ut under 1960-80-talet? I en publikation av karaktären rådgivningsmaterial för föräldrar fann jag bilder av »en närvarande och engagerad fader», "en vägledare och förebild", "en man med kontroll över sina känslor» och "fadern som familjeöverhuvud». Jag ställer också frågan om hur den ihågkomna praktiken av faderskap ser ut för ryska män som jag intervjuat, och hur de förhöll sig till de då rådande idealen? Kan vi se skillnader i betoning mellan officiella diskurser

\footnotetext{
^Kontaktinformasjon: Helene Carlbäck. Email: helene.carlback@sh.se
} 
och mäns berättelser? Utan att göra en regelrätt undersökning av eventuella öst-västliga skillnader i faderskap kommer jag avslutningsvis ändå att beröra den frågan.

I en värld där "det korta 1900-talets» öst-västliga geopolitiska, sociala och kulturella skiljelinjer så starkt har påverkat vår föreställningsvärld om politiska och ekonomiska, såväl som sociala och kulturella företeelser, menar jag att det är relevant att fråga sig hur faderskap i Sovjetryssland såg ut. Jämfört med idealbilder och praktiker i de delar av världen som vi brukar referera till som "Väst», ${ }^{2}$ vanligtvis den anglosaxiska världen, nordvästra Europa och Nordamerika, är våra kunskaper vanligtvis mycket mindre rörande det ryska faderskapet. Mitt fokus ligger i tidsperioden 1960-1989. För en bakgrund till den perioden vad gäller familjefrågor inleder jag med en kort översikt av den föregående sovjetryska tiden, med början i ryska revolutionen 1917.

\section{Historisk bakgrund}

Året 1917 leddes Ryssland in i nya fåror för familj, äktenskap och föräldraskap. Normer kring dessa frågor förlorade mycket av sin förrevolutionära karaktär om vi tittar till lagstiftning och offentliga diskurser. Kyrkan berövades sitt inflytande på familjeområdet, ett inflytande som tidigare hade hindrat reforminriktade jurister att få till stånd en moderniserad lagstiftning kring äktenskap och familj (Wagner 1994). Procedurerna kring ingående och upplösning av äktenskap förenklades nu, och under loppet av 1920-talet kom skilsmässor i Sovjetryssland att bli fria på ett sätt som inte hade setts till i övriga Europa under många hundra år; genom att den ena parten i äktenskapet skickade ett meddelande till folkbokföringsmyndigheterna om sin avsikt och vilja att upplösa äktenskapet, beviljades skilsmässan nästan omedelbart. Förfarandet kom i folkmun att kallas "postkortsskilsmässa». Män och kvinnor var i princip fria att lämna sina makar för nya partners utan att invänta långdragna byråkratiska procedurer och utan att behöva ange särskilda skäl till skilsmässan. Strax efter revolutionen beviljades kvinnor, lagmässigt, rätten till abort. Samtidigt likställde ett lagdekret barn födda utom äktenskapet med inomäktenskapliga barn, och därmed hade ensamstående mödrar möjligheter att få den man som identifierades av juridiska myndigheter som fadern, att betala underhåll för barnet. Stundtals kunde kvinnor peka ut flera potentiella fäder, som då gemensamt dömdes att betala (Goldman 1993; Carlbäck 2009; Chernova 2012: 46-47). Den biologiska kopplingen mellan fäder och deras barn blev därmed försvagad.

Också den intensiva rörelse av folkförflyttning och inre migration som karakteriserade den sovjetryska mellankrigstiden luckrade upp familjebanden. Stora grupper

\footnotetext{
${ }^{1}$ Jag använder här den brittiske historikern Eric Hobsbawms beteckning på en period, 1914-1989, som starkt färgades av en öst-västlig bipolär ideologisk konflikt (Hobsbawm 2003).

${ }^{2} \mathrm{Jag}$ är medveten om att begreppet "Väst» är ett begrepp som i vetenskaplig mening är hårt generaliserat; i det här fallet omfattar begreppet främst Väst- och Nordeuropa samt Nordamerika, områden med demokrati som dominerande politisk modell och en familjestruktur med kärnfamiljen som norm där individen har tydligare plats än släkten.
} 
av bönder, och särskilt de som gjorde motstånd när de berövades sin jordegendom i samband med den stora kollektiviseringsdriven, evakuerades och förvisades österut och norrut i landet och tvingades hitta sin utkomst bäst de kunde i de nya områdena. Andra internerades $i$ läger och många avrättades eller dog av sjukdomar och undernäring. Så skedde också med flera av landets nationella minoriteter, framförallt de som hade sina bosättningar i landets gränsområden - de kom att betraktas som potentiella femtekolonnare inför hotet om ett kommande storkrig med Nazityskland. Parallellt mobiliserades arbetskraft i stor skala till nyuppförda industrier och råvaruutvinnande orter med malmgruvor och oljefyndigheter (Fitzpatrick 2000; Hoffman 2003).

Kärnfamiljen som växt fram under 1700- och 1800-talet som ett ideal iVäst- och Nordeuropa omhuldades inte av den nya sovjetryska staten. Tvärtom talade landets första social- och familjeminister, Aleksandra Kollontaj, om nödvändigheten av att öppna upp den lilla familjen - ett borgerlighetens påfund och ett fängelse för kvinnorna - mot samhället och de kollektiva institutionerna (Rotkirch 2008: 90). I det här sammanhanget är det viktigt att även betona arvet från det östeuropeiska familjemönstret. Här framstår faderskapet som svagare än traditionen med pater familias enligt till exempel tyska eller franska familjenormer. Den familjemodell som historiskt präglat Ryssland utmärktes av utvidgade bondefamiljer med generationsmässigt kodade hierarkiska förhållanden, där det unga paret vanligtvis levde med mannens familj och den äldre generationen intog en maktposition (Laslett 1983).

Den efterrevolutionära familjepolitiken hade ambitionen att samhället skulle gå från en patriarkal familjemodell till en individualiserad. Ett exempel på detta var rätten för kvinnor och män att själva bestämma vem de skulle gifta sig med (Goldman 1993: 48-49). Delar av barnomsorg och uppfostran överfördes till kollektiva eller offentliga institutioner, såsom skolor, daghem och barnhem, och även till mor- och farföräldrar eller andra släktingar och till grannar i de kollektiva lägenheterna där åtskilliga familjer fick dela bostad. Att inte förglömma i sammanhanget är den stora förlusten i andra världskriget av ryska män, något som vidmakthöll situationen med frånvarande fäder i den mest konkreta betydelsen: de fanns inte i livet. ${ }^{3}$ Om de hade utomäktenskapliga barn befriades de enligt en ny familjelagstiftning 1944 från alla skyldigheter som fäder (Schlesinger 1949; Nakachi 2006; Carlbäck 2012).

Efter Stalins död 1953 fördömde de nya sovjetiska ledarna terrorn och det övercentraliserade och totalitära systemet. Statliga välfärdssystem byggdes ut och samtidigt började privatlivet få en återupprättelse (Zhidkova 2012: 47). Ett förnyat intresse för pedagogiska frågor förde upp ämnen kring barns utveckling och begreppet "personlighet» på den offentliga dagordningen (Field 2007: 84). Gränserna vidgades för vad som kunde talas och skrivas om i massmedia, till exempel kritik av

${ }^{3}$ För en analys av sovjetrysk skönlitteratur om frånvaron av fäder, se Snegireva \& Podtjinenov (2004). 
materiella brister i folks vardagsliv. En öppning mot en autentisk allmän opinion började (Zubkova 1998: 191-201), även om denna "halvoffentliga domän» behöll sina flytande gränser mellan det privata och det offentliga genom hela den sovjetryska perioden (Rotkirch 2000: xiii).

1960-talet, liksom även senare delen av 1950-talet, intar en framträdande position i det ryska historiska medvetandet - såväl folkligt, som fackhistoriskt. Perioden har kommit att kallas "tövädret» (ottepel). Den ses som en vattendelare mellan den regim, å ena sidan, som sedan oktoberrevolutionen 1917 grundat sitt maktmonopol på politisk och ekonomisk mobilisering uppifrån och periodvis på massrepression och terror och den sensocialistiska regim som från sent femtiotal och framåt försökte hitta mindre diktatoriskt styrda sätt för att utveckla samhället. Låt mig citera Michail Petrovitj, ${ }^{4}$ en av informanterna för min undersökning, när han talar om 1960-talet: "På foton från den tiden (...) ser man ofta män med håret djärvt bakåtstruket från pannan (...) de ser verkligen ut som fria människor» (MP 2015).

Decennieskiftet 1950-1960 bevittnade hur stat och samhälle slog ett slag för äktenskapsvänliga och familjepositiva värderingar. En ny familjebalk, som antogs i slutet av 60-talet, innehöll tydligare regler för äktenskap och skilsmässa och för utbetalning av underhåll för barn efter skilsmässa samt återupprättad möjlighet för ensamstående mödrar att begära faderskapsutredning och tilldömas underhåll från barnets far (Lapidus 1978: 239). Liksom i andra fall där högtider återinfördes i det sovjetiska livet under den här tiden - inte sällan med lånade inslag från förrevolutionära och kyrkliga traditioner - började vigslar att omgärdas av mer högtidliga former. Så kallade äktenskapspalats inrättades, och det blev populärt för kvinnor att bära vita klänningar och brudslöja och för brudparet att anlända till vigselceremonin i hyrda bilar, prydda med blomstergirlander och gyllene vigselringar i förstoring (McDowell 1974: 268-69, 275; Lebina 2017: 58-64).

En sovjetrysk motsvarighet till det svenska fenomenet "miljonprogram» realiserades under Chrusitjevregimen. Snabbuppförda lägenhetshus med för tiden moderna kök och badrum innebar att många människor för första gången fick enskilda bostäder. ${ }^{5}$ Ett exempel på representation i bildkonsten av denna förändring i människors liv, är Konstantin Pimenovs tavla "Bröllop på morgondagens gata» där ett ungt par i bröllopskläder balanserar på en spång lagd över leran i ett bostadsområde som håller på att byggas. ${ }^{6}$ Familjevärderingar och intresse för hemmet grep i ökande grad tag i människors medvetande (Shlapentokh 1989), och populärpressen innehöll tips om hur de nya hemmen kunde inredas (Reid 2004; Gradskova 2007). De domesticerande idealen var främst riktade till kvinnor, men drog också in männen.

\footnotetext{
${ }^{4}$ Samtliga informanter är anonymiserade och har andra namn i verkligheten.

${ }^{5}$ Boende i kollektiva lägenheter var dock en realitet för en relativt stor del av befolkningen under hela den socialistiska perioden i Ryssland.

${ }^{6}$ Tavlan visades nyligen på en uppmärksammad utställning i Moskva om 50- och 60-talets så kallade töväder (Karpova 2017).
} 
1960-talet kan ses som starten på mer utbredda krav på män att inte bara finnas i hemmet utan också att vara engagerade och närvarande i sin roll som fäder; viss offentlig kritik kunde höras mot den "dolda frånvaron av fäder» och "pappors passivitet i hemmet» (Chernova 2012: 43).

\section{Teori, forskningsmaterial och metod}

I min undersökning använder jag berättelser från mina informanter i interaktion med de idealbilder jag funnit i det tryckta materialet, tidningen Semja i sjkola. Detta genom att utforma intervjufrågor på basis av idealbilderna och tala med informanterna om hur de ställde sig till dessa bilder. Tidningstexterna har jag närmat mig med hjälp av teoretiska begrepp kring maskulinitet och faderskap, som jag utvunnit från historisk forskning om europeisk och nordamerikansk manlighet och faderskap. Jag beskriver dessa begrepp, eller idealbilder, nedan.

För att få en teoretisk grund för min studie har jag studerat internationell, främst anglosaxisk och nordisk historieskrivning och därifrån lyft fram dominerande idealbilder av 1900-talets faderskap och maskulinitet. För en hänvisning till forskningsöversikter på området har jag valt ut två verk (King 2015: 4-8; Lorentzen \& Ekenstam 2006). I forskningen definieras förhärskande idealbilder som förmågan att upprätthålla självkontroll, att besitta viljekraft, ärlighet, uthållighet och en kapacitet att arbeta hårt. Till detta kan läggas en förmåga att kontrollera sina känslor, att ha distans till känslor, eller en motvilja mot att tala om känslor som rör kärlek eller nära relationer (Matt 2011: 121). Samtidigt påpekas det $\mathrm{i}$ forskningen att mäns beroende av familjen har förstärkts i en tid då arbete i ökande grad blivit rutinartat, och sökandet efter självförverkligande genom professionella framgångar har minskat (Stearns 1979: 147). Ett tidigare mer exklusivt borgerligt ideal med hemmet i fokus för ett liv i kärnfamilj spred sig till andra samhällsklasser under 1900-talet.

Dock bör man vara försiktig med att teckna strikt lineära modeller för hur familjen omvandlas, eftersom förändringar i föräldraskap varken varit enhetliga eller slentrianmässigt förutsägbara. Det kulturella idealet för faderskap har således befunnit sig i ständig förändring under 1900-talet. Forskare inom fältet "känslornas historia» framhåller att det under senare delen av 1900-talet finns "mer av informella känslouttryck i en kontext av fortsatt tyngdpunkt på självkontroll» (Stearns 2008: 24).

Maskulinitet och faderskap i rysk historia är svagt utforskade ämnen $\mathrm{i}$ jämförelse med vad som är fallet i Väst. En del studier har dock genomförts i ämnet (Rotkirch 2000; Kukhterin 2000; Snegireva \& Podtjinenov 2004, Isupova \& Kon 2009; Haavio-Mannila \& Rotkirch 2010; Chernova 2012; Zdravomyslova \& Temkina 2013; Rodin \& Åberg 2014). Vad gäller den sovjetryska perioden tecknas en faderskapsmodell karakteriserad av marginaliserade fäder ersatta av en allians av arbetande mödrar, en stödjande sovjetisk stat (med omfattande system av förskolor, t.ex.) och 
ett utvidgat moderskap ${ }^{7}$ genom närvaron av mor- och farmödrar. I en studie hävdas att mamman i praktiken tog hela ansvaret inom familjen för alla delar av omsorg och fostran av barnen, ofta tillsammans med sin egen mamma (Rodin \& Åberg 2014: 26).

Tidsbudgetstudier från 1960- och 70-talen visar att ryska män (i städer) ägnade i genomsnitt hälften så mycket av sin tid, som kvinnor, till sysslor i hemmet även om tiden tillsammans med barnen var jämnare fördelad föräldrarna emellan, jämfört med att tvätta, laga mat och städa (Zuzanek 1980: 81). Samtidigt bör män ha tillbringat en relativt stor del av sin fritid i hemmet, eftersom de mest frekventa fritidsaktiviteterna var att lyssna på radio och att läsa tidningar och böcker (Zuzanek 1980: 90-93).

Mitt tryckta forskningsmaterial för att utröna officiella/offentliga diskurser om faderskap är den ryska månadstidningen Semja $i$ sjkola. Zjurnal dlja roditelej, „Familj och skola. En tidning för föräldrar», för åren 1960-1989. Jag har inte kunnat finna ut hur tidningen mottogs eller vilka som specifikt var dess läsare. Jag har dock utgått ifrån att den lästes ungefär på samma sätt som rådgivningsböcker för föräldrar. Jag har också gjort antagandet att läsarna var relativt välutbildade, samt att majoriteten var kvinnor.

Efter en genomgång av artiklar i 29 årgångar med vardera 12 nummer per år, särskilt ägnade frågor om faderskap - det rör sig om i genomsnitt 3 artiklar per nummer - sorterade jag ut några av de mer frekventa faderskapsidealen med vars hjälp jag formulerade frågor till mina informanter. Följande idealbilder av faderskap träder fram: en närvarande och engagerad fader, en vägledare och förebild, en man med kontroll över sina känslor och fadern som familjeöverhuvud.

Mina informanter är elva män i åldern 50-75, alla gifta och, med ett undantag en informant från Perm - bosatta i Sankt Petersburg. ${ }^{8}$ Deras sociala status sträcker sig från lägre medelklass med yrkesskoleutbildning som bakgrund, till medelklass med akademisk utbildning. Samtliga är gifta fäder. Vad gäller frånskilda fäder kan bilden bli annorlunda, med män ovilliga att betala underhåll för sina barn och som undvek att träffa dem, och i stället gick in för sina barn i ett nytt äktenskap. ${ }^{9}$

Urvalet av informanter har främst gjorts via far- och morföräldrar till en rysk sociologs bekanta eller "bekantas bekanta». Sociologen, Ekaterina Ivanova från Europauniversitetet i Sankt Petersburg, var också min medintervjuare. Intervjuerna är av semi-strukturerad karaktär, djupintervjuer av en tidslängd från 1,5 till 2,5 timmar.

Med mitt begränsade antal intervjuer gör jag inte anspråk på att visa upp en representativ bild. Ändå menar jag att mina resultat kan bidra till en mer diversifierad

\footnotetext{
${ }^{7}$ För ett resonemang kring begreppet "extended mothering» som en variant av "extended family» och som en kontrasterande modell till »intensive mothering», se Rotkirch (2000: 116-120).

${ }^{8}$ I slutet av min artikel finns en förteckning över informanterna med förkortningar av deras anonymiserade namn, ålder, yrke, antal barn och hur länge de varit gifta.

${ }^{9}$ Ingegerd Municio-Larsson har intervjuat frånskilda män i postsocialistiska Estland och Lettland och visar på en hög grad av frånvaro av aktivt faderskap, med rötter i skilsmässovanor från sovjettiden (Municio-Larsson 2012: 273-295).
} 
bild av det sovjetryska faderskapet. Det ska betonas att alla mina informanter lever i städer. Jag känner inte till studier om sovjetiskt faderskap i miljöer på landet, men i samtal med en ryskfödd kollega, 36 år, stationerad vid ett finländskt universitet, fick jag höra en historia om familjeliv i en liten sibirisk by. Min informant betonade hur annorlunda familjelivet var där, jämfört med i städerna: „Där rådde en mycket patriarkal kultur» (VS 2016).

Dessa män intervjuade jag om deras minnen av att ha varit fäder och deras uppfattningar om hur en idealisk pappa skall se ut. Jag är medveten om problemet med att tala med människor om saker som hänt trettio-femtio år tillbaks i tiden, och jag utgick ifrån att mina informanter var påverkade av dagens ryska attityder till faderskap och famili, attityder som kan skilja sig från tidigare skeden i historien. Den ryska historikern Elena Stiazhkina säger om detta metodologiska problem, att »de som minns (ändå) är opålitliga vittnen (...) eftersom det förflutna romantiseras och upplevs som mer sanningsenligt och möjligt att få grepp om, när det ställs i konflikt med nuet (Stiazhkina 2012: 65). Alla intervjuer började med att jag bad männen att berätta sitt livs historia. Här fanns saker som de verkade ha pratat om många gånger förut. Narrativ hade skapats som förmodligen förändrats, modifierats och förhandlats fram under deras livstid, såsom historier om barndomen under andra världskriget, hungerblockaden i Leningrad, folkförvisningar i andra världskrigets slutskede, politiska och sociala förändringar som ägde rum efter Stalins död eller de stora omställningarna som Gorbatjovs perestrojka förde med sig. Det visade sig dock att frågor av typen: „Hur ska en god pappa vara?» inte verkade vara något mina informanter funderat särskilt mycket på.

\section{Idealbilder i tidningen Semja $i$ sjkola}

"Hur många fantastiska strofer inom poesin finns det inte som hyllar modern och det heliga moderskapet. Alldeles för lite har skrivits om faderliga känslor, knappast något alls. Det är verkligen en brist eftersom fäder har en särskild roll i familjeliv och barnuppfostran» (Semja, 1964, nr 2: 2). Med detta citat markerade tidningen Semja $i$ sjkola (Familj och skola) att faderskap inte var ett tillräckligt uppmärksammat tema i samtidens diskurser. Min läsning av tidningen har syftat till att söka återkommande idealbilder där den sovjetryske fadern är en aktiv familjemedlem.

"I en del familjer härskar fortfarande den felaktiga föreställningen att modern ensam har ansvaret för barnens fostran", skriver tidningen i tidigt 1960-tal (Semja 1961, nr 8: 7-9). Män kritiseras för att inte vara tillräckligt närvarande och engagerade: "Han må vara aldrig så pratsam och artig, humoristisk och avspänd när han är på jobbet, borta hemifrån. Men så fort han kommer hem blir han omöjlig att kommunicera med, som om orden fastnat i halsen på honom» (Semja 1961, nr 8: 7-9).

I slutet av 60-talet publicerade tidskriften en serie artiklar under titeln "En pappas dagbok», bestående av kommentarer och iakttagelser om dottern Valja från det hon var två till det hon var sju år gammal. Det var ett »ovanligt drag», skrev 
chefredaktören, att trycka ett sådant material (Semja 1967, nr 9: 5). Dagboken hade en framträdande plats långt framme i tidskriften och kan ses som exempel på det återuppväckta intresset för pedagogik och barnuppfostran i Sovjetryssland. Som läsare får man intrycket av att det är en professionell pedagog eller psykolog som skriver, någon som oavbrutet reflekterar över barnets olika utvecklingsstadier. Ett fadersideal förmedlas med principfast uppträdande gentemot barnet, samtidigt som det finns tålamod och förståelse. Barnet ska skaffa sig en moralisk kompass och förmåga till självbehärskning (Semja 1967, nr 6: 22). I en annan artikel framhålls pappans roll som vägledare i barnets val av studiegång: „En pappa kan hjälpa sitt barn att välja för det framtida yrkeslivet, inte bara innehållsmässigt utan också från en moralisk utgångspunkt» (Semja 1961, nr 8: 7-9).

En diskurs i Semja $i$ sjkola som gör sig starkare påmind från mitten av 70-talet är att pappan ska vara vägledare och förebild särskilt för pojkarna: „Fadern ska vara en förebild för sin son, hjälpa honom att utveckla äkta manliga egenskaper, såsom mod, självbehärskning och generositet» (Semja 1982, nr 3: 23-24). I tidningen generellt finns ett underliggande antagande om att män och kvinnor är i grunden olika, särskilt i texter från sent 70-tal och från 80-talet: »Moderskänslor är inneboende medan faderskänslor är förvärvade», sägs det i en artikel (Semja 1982, nr 3: 23-24) och i en annan att "det kvinnliga psyket är mer emotionellt medan män har en inneboende drift att ta sig bort från hemmets härd» (Semja 1982, nr 3: 36-38). Flera forskare har pekat på framväxten av ett tydligare könsrollstänkande, med biologistiska drag, under 70-talet (Attwood 1990; Liljeström 1995).

Idealbilden av fadern som en man med kontroll över sina känslor möter läsaren i olika texter i Semja $i$ sjkola. En artikel lyfter fram hur fint det är med en närvarande och engagerad fader, men fogar till detta en varning för att bli alltför nära, att vara för mycket av en kamrat: "Det är utmärkt när barnen ser att pappa finns med i deras uppfostran. Men det finns ingen anledning att hamna i det extrema (...) en fader ska inte visa överväldigande kärlek för sina barn» (Semja 1974, nr 2: 6-7).

När jag letade efter texter av det här slaget försökte jag finna råd som varnade för manligt våld i familjen, mer explicit. En artikel talar om rätten för en far att vara krävande och sträng, något som skribenten blivit övertygad om efter sin mångåriga erfarenhet som lärare. Men han varnar för risken att falla in i grymhet och brutalitet: "Det får inte förekomma!» (Semja 1979, nr 2: 17-21). Det föreskrevs en balans mellan stramhet och en alltför hård behandling. Den relativt höga alkoholkonsumtionen bland män i Sovjetryssland, särskilt från 1970-talet och framåt var ett ämne som togs upp i tidningen.

Bilden av fadern som familjeöverhuvud återkommer med jämna mellanrum i tidningen. Enligt en opinionsundersökning presenterad 1973 i tidningen av sociologen Anatolij Chartjev, ${ }^{10}$ ville kvinnor se egenskaper hos män som överensstämde med

${ }^{10}$ Chartjev (Kharchev) har sedermera kommit att betraktas som en huvudaktör när den efterkrigstida sociologin återupprättades i Sovjetryssland, och en pionjär med sina opinionsundersökningar om kärlek och sexualitet. 
ett ideal för "familjens överhuvud», nämligen förmågan att vara fokuserad och självbehärskad, att besitta inre balans och uthållighet och att vara nykter (Semja 1973, nr 2: 24-25).

\section{Analys av informanternas berättelser}

\section{En närvarande fader}

För att få en förståelse av i vilken mån männen varit närvarande i familjen frågade jag hur arbetsfördelningen för barnomsorg och skötsel av hushållsgöromål sett ut makarna emellan. Ett typiskt svar var att det inte funnits någon särskild uppdelning av sysslor. Jag nöjde mig dock inte med utsagorna om att alla hemsysslor hade skötts mer eller mindre spontant, utan frågade mer konkret om vem som hade gjort vad i hemmet. Nästan alla informanterna nämnde att de hade "skurat golv». Detta kan verka förvånande vid första ögonkastet, men vid närmare eftertanke kom en enkel förklaring för mig: De sovjetiska lägenheterna var ofta utrustade med en gammaldags typ av parkettgolv med porös yta, vars rengöring krävde ett hårt arbete av skurande och ibland efterföljande boning.

Ett förväntat svar var att männen hade tagit hand om elektricitet, rörmokeri samt snickeri- och renoveringsarbeten. Mindre väntat för mig var att de hade gjort en hel del av familjens inköp. I Sovjetryssland där konsumtionssektorn var underutvecklad i förhållande till produktionssektorn (främst den tunga industrin) innebar att gå i affärer ofta att "jaga» matvaror eller andra nödvändigheter till hemmet. Pjotr Olegovitj, 62, från staden Perm vid Ural, berättade om den påtagliga bristen på dagligvaror på den öppna konsumtionsmarknaden: "Det fanns faktiskt ingenting att få tag på. Men vi såg det inte som någon katastrof. Det bara var så. Man fick lösa problemet (...) använda sina kontakter. Till exempel i den stad vi bodde i [Perm] fanns inga möbler att få tag på i affärerna. Men alltså (...) alltså, det var bara att söka vidare (...) fånga ögonblicket. Inget märkvärdigt med det: lös problemet, sade man till sig själv. Att få tag på varor var som att gå på jakt» (PO 2015).

Michail Grigorovitj, 75, hade under småbarnsperioden levt i en av de centralasiatiska sovjetrepublikerna, där, enligt honom, könsrelationerna skilde sig från de ryska: detta i fråga om kvinnors underordning. Han hade varit den som tvättade tygblöjorna, något som han dock aldrig pratade om på sitt jobb eller med bekanta (MG 2015).

I samtalen om vem som gjorde vad i hemmet inkluderades inte sällan mormor och/eller farmor (då och då även morfar och farfar). Åtta av de elva informanterna hade bott tillsammans med den äldre generationen, särskilt medan barnen varit minderåriga.

\section{Emotionellt faderskap}

Resonemangen om att vara en närvarande fader fick oss in på ämnet att vara känslomässigt närvarande. Jag frågade männen vilka minnen de hade av ögonblicket när deras barn hade fötts. Vi fick olika slags svar. En förvånad reaktion kom från Michail Grigorovitj, 75: „Vad menar ni med den frågan (...) jag kände mig som vanligt!» (MG 2015). Michail Petrovitj, 52, förmedlade en stark känsla: „Första gången jag höll henne i mina armar var 
jag så rädd att tappa henne (...) jag får inte tappa henne, jag får inte tappa henne, sade jag till mig själv (...) men så lade jag mig ner på sängen och hon började snusa så fint och lugnt och snart hade jag också somnat. Vi låg där i en halvtimme eller så» (MP 2015).

De av männen som uttalade sig mest emotionellt om minnena av sina barns första tid var de yngsta, eller de som fått barn senare än de övriga. Andrej Leonidovitj, 60 , talade om sig själv som den mer känslomässiga av de två föräldrarna $i$ familjen. Han verkade dock värdera den egenskapen som ett omanligt karaktärsdrag: "Jag är som en mamma (...) jag vet inte om det är min personlighet helt enkelt» (AL 2016).

I allmänhet uttryckte informanterna inte känslor av ånger eller skuld över att de skulle ha varit för litet engagerade som fäder. En av historierna förmedlar dock skuldkänslor på ett kännbart sätt. Pjotr Olegovitj, 62, skilde sig från sin första fru när den yngsta dottern var åtta år och under intervjun uttryckte han frustration och sorg över den perioden i sitt liv. Orsaken till skilsmässan var att han förälskat sig i en annan kvinna, som han beskriver som "mitt livs kärlek». Intervjun var den enda jag inte själv tog del i och jag har därför bara hört resultatet på ljudupptagning. När samtalet mellan honom och min ryska kollega vid olika tillfällen kommer in på skilsmässan och separationen från dottern förändras rösten. $\mathrm{Nu}$ och då kan man höra hur det stockar sig i halsen och det blir det långa pauser. De sitter på ett kafé och man hör hur han rör häftigare och mer ljudligt med skeden i kaffekoppen (PO 2015).

När vi kom in på männens praktiker, det vill säga hur de konkret hade använt sin tid blev det uppenbart att de hade varit borta mer från hemmet än vad deras hustrur varit. Oftast försvarades detta med att de hade jobbat mer.

Faktorn "arbete» som en uppgiven orsak för att inte ha deltagit var av olika karaktär hos olika informanter. Sovjetunionen var ett vidsträckt land med en centraliserad ekonomisk styrning, något som gjorde mobiliteten relativt stor. Arbets- eller tjänsteresor var inte sällan ett extra tillskott till familjebudgeten. Särskilt inkomstbringande var utlandsresor. Georgij Davidovitj, 75, hade arbetat i ledande ställning vid installationen av sovjetproducerade vattenkraftverk och turbinanläggningar $i$ Kuba,Vietnam och Pakistan och tjänat ekonomiskt så bra på dessa arbeten att familjen lyckades mycket snabbt betala av lånet på sin bostadsrättslägenhet. Den typen av lägenheter, så kallade kooperativa lägenheter, hade börjat byggas under slutet av 1960-talet och kom att bebos av familjer med relativt hög inkomst (Attwood 2010: 158-161), såsom Georgij Davidovitjs familj där båda makarna hade högre utbildning och arbetade som civilingenjörer.

Detta innebar att han var en hel del frånvarande från familjen när hans två barn var små. Samtidigt arbetade hans hustru heltid under hela deras familjetid, med undantag av de cirka 10 månader som hon satt hemma med barn efter födseln. Detta arrangemang möjliggjordes av att mannens mor levde tillsammans med hans familj och deltog i hög grad i hushållsgöromålen och barnomsorgen. Ingen av hustrurna hade ägnat sig åt resor $\mathrm{i}$ jobbet. Tvärtom hade en del av dem anpassat sitt arbetsliv på ett sätt som gjorde att det blev lättare för dem att kombinera sitt heltidsarbete med 
huvudansvaret för familjens barnomsorg. Så till exempel, hade en av fruarna arbetat som barnläkare på den förskola, dit hon också såg till att hennes barn hamnade. En annan hustru hade varit sjuksköterska på barnens daghem. Några kvinnor hade sett till att skaffa arbete nära barnens förskola för att lättare kunna hämta och lämna dem. Inte någon av de tillfrågade männen berättade om att de skulle ha organiserat en sådan koppling mellan val av arbetsplats och närhet till barnens daghem eller skola. Det ska sägas att flera av fäderna också hämtade och/eller lämnade barnen på daghemmen, men det övergripande ansvaret låg uppenbarligen på kvinnorna.

Georgij Davidovitj var den enda av som öppet tillstod att arbetet varit viktigare för honom än hans familj. Samtidigt talade han med stolthet om sin dotter som idag har en hög position inom ett storföretag och det kändes att han såg sig som den i familjen som främst påverkat hennes karriärval.

\section{En man med kontroll över sina känslor}

När vi hade pratat färdigt om faderskänslorna så hade vi en blandning av historier om mer eller mindre starka känslor för ögonblicken kring barns födelse, å ena sidan, och narrativ om nödvändigheten för en man att kontrollera sina känslor, å den andra: "Jag var rak med mina söner, inget gullande", underströk Pjotr Aleksandrovitj, 75 (PA 2015), medan Georgij Davidovitj, också han 75, förklarade att han inte brukade pussa och krama sina döttrar: "Det fanns inte egentligen något behov av sånt (...) som pappa måste man kontrollera sitt beteende» (GD 2015). Andrej Leonidovitj, 60, var den enda som explicit hyllade den lekfulle fadern som ett ideal. Jämfört med de övriga informanterna framstår han som del av en annan generation av fäder. Han är inte den yngste, men han har fortfarande små barn, tio och tre - utöver två äldre barn som han har från andra förhållanden. På grund av olika omständigheter är numera hans (tredje) hustru familjens huvudförsörjare. Själv har han tagit ut föräldrapenning som pappa och hans syn på den ideala fadern uttryckte han så här: „En bra pappa är en som älskar sina barn och som tar med barnen till dom ställen barnen själva vill gå» (AL 2016). På mig gör Andrej Leonidovitj intryck av att vara en ny tids pappa.

\section{Vägledare och förebild}

När vi samtalade om känslor för barnen och olika sätt att vara nära sina barn genom att leka med dem eller att vara vägledare i deras val av studier eller yrke - så hörde vi växlande uppfattningar om huruvida fadern skulle vara auktoritet eller lekkamrat. Pjotr Aleksandrovitj, som hade barn (två söner) på 60-talet, brukade vara mycket tillsammans dem, de gick och fiskade, byggde modelljärnväg eller fixade det elektriska systemet hemma. Men när vi frågade honom om vad ett gott faderskap framförallt innebar för honom, så talade han inte om den lekfulle fadern som ett ideal. I stället betonade han rollen som vägledare (PA 2015). När jag frågade om fäder borde vara vägledare stannade informanterna ofta upp och funderade ett slag. Georgij Davidovitj, 75, säger: »Ja (...) alltså (...) en man är ju som han är (..) han arbetar mycket. Han ska framförallt se till att hans barn klarar konkurrensen i livet» (GD 2015), medan Michail Grigorovitj, 75, framhåller att fadern ska vara lärare och 
vägledare medan barnet är litet, men "när det har vuxit upp kan man vara mer som vänner med varandra» (MG 2015).

För att djupare komma åt vad informanterna ansåg vara ett gott faderskap bad vi dem berätta om sina egna fäder - hade de varit närvarande fäder? Genomgående blev svaret att pappan hade arbetat mycket. Vi frågade då om de hade saknat sina fäder. Men i svaren hittade vi egentligen inte några känslor av förlust. I stället hörde vi dem säga saker som: »Jag tänkte aldrig på det viset» (AI 2016). Informanterna förmedlade en bild av familjer där stundtals ingen av föräldrarna var särskilt kontrollerande eller närvarande, båda föräldrarna hade arbetat hårt. I det sammanhanget underströk Georgij Davidovitj, 75, betydelsen av det omgivande samhället, till exempel skolan, som en disciplinuppehållande faktor: „Föräldrarna ägnade sig inte särskilt mycket åt mig (...) men lärarna var mycket krävande och mycket skickliga» (GD 2015).

Samtidigt försäkrade männen att deras fäder hade varit goda förebilder. Detta med undantag av en informant som vuxit upp med en alkoholiserad pappa. Flera nämnde att de hade valt samma yrke som sin far: »Ja [min pappa var en förebild för mig] ju äldre jag blev. Jag ville också bli sjökapten» (OP 2016).

Jag frågade dem om böcker och tidskrifter av rådgivningskaraktär - hade de brukat läsa sådant? De flesta slog bort tanken, ofta med ord av typen att det inte behövdes, eftersom det där med att vara tillsammans med barn var en naturlig sak: "Min hustru läste Semja $i$ sjkola och böcker om barnuppfostran, men sånt hade ingen betydelse för mig», säger Vladimir Petrovitj, 53 (VP 2016) och Michail Petrovitj, 52, tyckte att tidningen gav "fåniga, innehållslösa, råd» (MP 2015). Idén om fadern som den medvetne läraren uttrycktes som ett ideal av dessa män, när jag särskilt frågade om det, men jag undrade för mig själv i hur hög grad dessa ideal faktiskt utövades i praktiken. Den tanken förstärktes när jag fick veta att de flesta fallen var det kvinnorna som deltagit i olika slags föräldramöten i skolan.

Ytterst sällan förekommer texter i Semja i sjkola som framhåller fäder som förebilder för sina söner när det gällde att försvara fosterlandet. Detta förvånade mig med tanke på hur militariserat Sovjetryssland var och fyllt av patriotisk propaganda - som en av de två supermakterna under kalla kriget. Jag hittade bara en artikel av det slaget. Den handlar om en man som känner osäkerhet för hur han ska vara som pappa. Först när han berättar om sina upplevelser under andra världskriget och om hur hans egen far stred vid fronten, känner han sig ge sin son en förebild i livet (Semja 1981, nr 3: 32-33). Den ryska genusforskaren Elena Mesitjerkina skönjer ett implicit faderskapsideal i diskurser om patriotiska män (Mesjtjerkina 1996). Jag kom dock inte att tala med mina informanter om den frågan.

\section{Fadern som familjeöverhuvud}

När jag tog upp frågan om huruvida mannen borde ta på sig rollen av att vara familjeöverhuvud kopplade jag ihop det med att vara den i familjen som tjänar mest. Några informanter var tydliga med att framhålla hur viktigt det var för männens självkänsla att de tjänade mer än hustrun. "Om kvinnan tjänar mest, vilken uppgift 
har då mannen (...) egentligen?», frågade sig Pjotr Aleksandrovitj, 75 (PA 2015). Andra pratade om risken att omgivningen skulle förakta dem. Vid den tiden tjänade kvinnor i Sovjetryssland i genomsnitt 70 procent av vad män gjorde (Lapidus 1978: 193). Samtidigt kan männen inte betraktas som familjeförsörjare, även om de tjänade mer, eftersom nästan alla vuxna kvinnor förvärvsarbetade, vanligtvis på heltid.

Det fanns dock andra röster om att vara den som tjänar mest. Som jag nämnt tidigare hade några av männen under sitt yrkesliv upplevt Gorbatjovs ekonomiska reformer i det sena 1980-talet, då nya marknadsekonomiska element såsom »kooperativt» ägda småföretag i servicebranschen kunde vända upp och ner på en tidigare ordning och tillåta att kvinnor tjänade mer än sina makar. Dessa män var mindre tvärsäkra i sina svar och kunde, som Ruslan Andrejevitj, 50, säga: „Varför skulle det behövas att en man tjänar mer (...) det är ju en rätt idiotisk idé!» (RA 2016), eller »Jag vet inte vem av oss som tjänat mest pengar - spelar det verkligen någon roll?» menade Nikolaj Aleksejevitj, 50 (NA 2016).

Det är intressant att se den beredvillighet som informanterna hade att beskriva sig själva som familjens överhuvud. Jag hade inte möjlighet att få den andra sidans - hustruns - syn på saken, men det kan noteras att den ryske sociologen Sergej Kukhterin, som också intervjuat fäder, hävdar tvärtom att kvinnan var den uppenbara ledaren för familjen (Kukhterin 2000: 84-85). Mina försök att koppla ihop rollen av att tjäna mest och att vara familjeöverhuvud var inte något som informanterna nappade på. Flera av dem betonade i stället att det var den som var mest erfaren eller "moraliskt» högtstående som naturligt blev familjens överhuvud. De flesta var ganska tydliga med att de själva varit familjens ledare.

\section{Informanternas berättelser $i$ ljuset av offentliga idealbilder}

Så har vi frågan om huruvida det faderskap som männen talade om, matchas väl med diskurserna i tidningen Semja $i$ sjkola? Innan vi går in på den saken bör vi erinra oss att männen svarat att de inte läste tidningar av det slaget. Flera berättade att deras hustrur läst den men att de inte själva tyckt sig ha behov av det. Jag skulle ändå hävda att råden i tidningen återspeglade en dominerande offentlig diskurs vid denna tid. Vi kan då föreställa oss en påverkanskedja av följande slag: Kvinnor, särskilt ur medelklassen, läste tidningen och berättade innehållet för sina män. Lärare läste tidningen, och mina informanter uppger att det var deras fruar som besökte föräldramöten och hade andra kontakter med barnens skola. Där förmedlades, kan vi gissa, olika slags råd om barnuppfostran som också vidarebefordrades till fäderna, när makarna diskuterade sina barn hemma. En av männen berättade att hans hustru läste tidningen, och talade med honom om det: "Så här skriver Semja $i$ sjkola (...) och då ska vi också göra så, sa min fru (...) och jag lydde henne» (MG 2015).

Om vi summerar samtalen vi hade om hur en god fader ska vara, liknar informanternas idealbild i rätt stor utsträckning den vi finner i tidningen Semja $i$ sjkola om den närvarande fadern. Tidningen manade män att vara närvarande. I samtalen med informanterna om deras tidsanvändning blev det uppenbart att de varit borta mer 
från hemmet än vad deras hustrur varit. Oftast försvarades detta med hur männen tvingats jobba mer. Samtidigt framstår det som att de tillbringat större delen av sin tid i hemmet. De tycks i tämligen hög grad varit fysiskt närvarande fäder - ibland "avlägsna närvarande», ibland "engagerade närvarande» fäder.

En diskurs i Semja $i$ sjkola som gjorde sig starkare påmind från mitten av 70-talet är att pappan ska vara vägledare och förebild särskilt för pojkarna. I tidningen generellt finns ett underliggande antagande om att män och kvinnor i grunden är olika, särskilt i texter från sent 70 -tal och framåt. Moderskänslor är nedärvda medan faderskänslor förvärvats. Informanterna är inne på samma spår, och säger att modern är den viktigaste personen under de första åren av barnets liv, eller att mammor är mjukare till sin karaktär jämfört med papporna.

Vad gäller frågan om mäns kontroll över sina känslor så ansåg merparten att detta var en viktig sak. Det var något som förväntades. Semja $i$ sjkola skriver om behovet av att fäder leker med sina barn, men att det har gått för långt när de »känner sig som sitt barns kamrat» (Semja 1974, nr 2: 6-7).

\section{Diskussion}

Under den period jag har undersökt hade den äldre generationen i Sovjetryssland, och då framförallt mor- och farmödrar, en framträdande roll $i$ att underlätta för barnfamiljerna, särskilt för kvinnorna som hade den tyngsta bördan av hemmasysslor samtidigt som de förvärvsarbetade på heltid. Detta är något som fått forskare att tala om sovjetryska män som onödiga och överflödiga i familjerna (t.ex. Rodin \& Åberg 2014). Mina intervjuer ger inte en sådan entydig bild, och det är ett resultat som får stöd av tidsanvändningsstudier rörande 60- och 70-talet (det finns inte heller skäl att tro att balansen i arbetsfördelning ha avsevärt skulle ha förändrats under 80-talet). Enligt dessa studier ägnade sovjetryska män en betydligt större del av sin fritid åt hemsysslor jämfört med män på flera håll i Europa vid samma tid, särskilt i Väst (Robinson, Converse \& Szalai 1972: 126).

Efter samtalen med mina informanter om hur faderskapet utövats i praktiken framträder en mer diversifierad och motsägelsefull bild, såtillvida att flera av de tillfrågade männen beskriver hur de utövat ett emotionellt nära faderskap, samtidigt som de framställer känslomässig distans som ett ideal. Vad gäller mäns kontroll över sina känslor ansåg informanterna att detta var en viktig sak. Det var, som vi sett, något som förväntades. Samtidigt delade de med sig berättelser om nära och intima känslor gentemot sina nyfödda barn och ibland också om känslor av skuld för att inte ha varit tillräckligt närvarande som fäder.

I samtalen kom jag in på en intergenerationell aspekt av faderskap. Jag ville fånga förändring mellan fadersgenerationerna före och efter sextiotalet. Och då kunde jag höra männen säga, som med en röst, att deras fäder varit för upptagna av arbete för att kunna vara riktigt närvarande som fäder. Detta bekräftar bilden av det tidiga Sovjetryssland då män förväntades att ägna sig betydligt mer åt kollektiva och samhälleliga 
sysslor och uppgifter, än åt privata familjeangelägenheter. Men mina informanter uttryckte inga negativa känslor gentemot detta faktum, inga särskilda känslor av förlust eller saknad. Till det kan jag tänka mig flera förklaringar. Etnografen Tommi Hoikkala, som undersökt ryska faderskapsdiskurser, lyfter fram en fadersauktoritet som förmedlas från generation till generation (Hoikkala 1998: 28-29) - detta mycket mer påtagligt än i motsvarande finländska diskurser som Hoikkala studerat.

Som en annan förklaring kan man tänka sig själva begreppet "frånvarande fäder» som ett delvis socialt konstruerat fenomen. Den svenska sociologen Thomas Johansson intervjuade på 1990-talet män i trettio-femtioårsåldern om deras fäder. Resultatet blev berättelser som genomsyras av saknad och smärta över att inte ha fått möjligheten att lära känna papporna och därmed inte fått en förebild i livet (Johansson 1998: 319, 329). Johansson drar dock slutsatsen att bilden av den frånvarande fadern $\mathrm{i}$ viss utsträckning är en stereotyp som döljer en verklig fader som ofta har stimulerat sin sons sökande efter kunskap. Dagens män, skriver författaren, har ibland fastnat i en förstelnad bild av sina fäder som formats och tidvis förstärkts av "moderns blick». Fadern konstrueras som "den Andre» (Johansson 1998: 319). I anslutning till Johansson kan man tänka sig att vad vi ser är delvis en västlig kulturell konstruktion, där upplevelsen av förlust förstärkts av normen om kärnfamilj, liksom av influenser av ett psykoanalytiskt tänkande, något som var frånvarande under större delen av den sovjetiska eran i Ryssland. Litteratur av det slaget dök inte upp förrän i det sena 1980-talet (Rotkirch 2000: 142).

I min inledning talar jag om hur vår del av världen under 1900-talet har dominerats av öst-västliga skiljelinjer i synsättet på sociala och kulturella företeelser. Min studie har inte ägnats åt någon undersökning av öst-västliga skillnader $\mathrm{i}$ faderskap, men på grundval av historikern Peter Stearns' forskning om nordamerikanska förhållanden, ${ }^{11}$ har jag några reflektioner rörande skillnader och likheter i att vara närvarande fader, att vara en förebild och att vara vägledare - i olika kulturella kontexter under samma tidsperiod.

Amerikanska kvinnor hade ansvaret för den övergripande planeringen av barnomsorg och hushållssysslor, medan män visade få tecken på att ta initiativet när det kom till vardagsaktiviteter av det slaget (Stearns 1979: 162). De ryska informanterna var ibland "avlägset närvarande», ibland »engagerat närvarande» som fäder, men huvudansvaret för hem och barn låg alltid på kvinnorna, både i ideal och praktik. Vad beträffar idealbilden av att vara familjens överhuvud uttrycks detta tydligt av de intervjuade ryska männen och även av tidningen Semja $i$ sjkola. Peter Stearns hävdar att få amerikanska män vid den tiden skulle ha beskrivit sig som familjens överhuvud, men en hel del skulle i realiteten ha sett sin hustru som "junior partner» i familjen när det kom till att fatta "de stora besluten» (Stearns 1979, 159-60). De ryska männen omhuldade i samtalen idealet att en fader skulle vara mer bestämd

${ }^{11}$ Förhållanden som jag menar är giltiga för ett generaliserat västeuropeiskt faderskap - med undantag av det nordiska under 70 - och 80 -talet 
mot sina barn än modern. Han skulle inte vara för nära och för mycket kompis - han skulle vara en moralisk vägledare. Forskningen om det amerikanska faderskapet visar upp en idé om fader som lekfull pappa, som var starkare än i Sovjetryssland. En påtaglig förändring ägde rum där under 1900-talet från ett auktoritärt förhållande till en mer kamratlig relation (Stearns 1979, 64-65). Min undersökning pekar mot att det sovjetryska pappaidealet var mer strikt, med en betoning på att fadern inte fick förlora betydelsen ur sikte av att vägleda sina barn; han hade en given auktoritet.

Det sovjetryska faderskapets ideal och praktik under de sista tre decennierna av den statssocialistiska eran framstår i min studie som inte så annorlunda jämfört med Väst. Även om den politiska diskursen i Sovjetryssland under det kalla kriget fortsatte att domineras av en marxistiskt färgad propaganda därVäst utmålades som "den Andre», skedde i realiteten ett närmande till Väst från rysk sida på till exempel familjepolitikens område. Regimen hade behov av att stabilisera läget efter konvulsionerna under Stalintidens stora sociala och ekonomiska förändringar av landet (tvångskollektiviseringen av jordbruket, den massiva och snabba industrialiseringen och den omfattande migrationen av människor över landet). Faderskapsidealen började nu påminna om den västliga »borgerlighetens» ideal sedan sent 1800-tal. Man kan uttrycka det så, som att det inte fanns några passande marxistiska instrument i den ideologiska verktygslådan att förändra familjepolitiken med. Den radikala nedmonteringen av en traditionell familjestruktur med fri skilsmässa, rätt till abort och ensamstående mödrars rättighet att få underhåll, samt, senare, 1944 års lags befrielse av män från ansvar för utomäktenskapligt födda barn, allt detta hotade den samhälleliga stabiliteten med familjen som grundsten.

\section{Om artikkelen}

Jag vill tacka mina fackgranskare vars arbete har förbättrat kvaliteten på min artikel.

\section{Referenser}

Attwood, Lynne (1990) The New Soviet Man and Woman: Sex-Role Socialization in the USSR. Bloomington: Indiana University Press.

Attwood, Lynne (2010) Gender and Housing in Soviet Russia. Private Life in a Public Space. Manchester: Manchester University Press.

Carlbäck, Helene (2009) "Lone Mothers and Fatherless Children. Public Discourse on Marriage and Family Law» i Melanie Ilic \& Jeremy Smith (red.) Soviet State and Society under Nikita Khrushchev. London: Routledge (86-103).

Carlbäck, Helene (2012) "Lone Motherhood in Soviet Russia in Mid-20th Century - in a European Context» i Helene Carlbäck, Yulia Gradskova \& Zhanna Kravchenko (red.) And They Lived Happily Ever After: Norms and Everyday Practices of Family and Parenthood in Russia and Eastern Europe. Budapest: CEU Press(25-46).

Chernova, Zhanna (2012) »The Model of 'Soviet Fatherhood'. Discursive Prescriptions». Russian Studies in History 51 (2): 35-62.

Field, Deborah (2007) Private Life and Communist Morality in Khrushchev's Russia. New York: Peter Lang.

Fitzpatrick, Sheila (red.) (2000) Stalinism: New Directions. London: Routledge.

Goldman, Wendy (1993) Women, the State and Revolution: Soviet Family Policy and Social Life, 1917-1936. Cambridge: Cambridge University Press.

Gradskova, Yulia (2007) Soviet People with Female Bodies: Performing Beauty and Maternity in Soviet Russia in the Mid 1930-1960s. Södertörn Doctoral Dissertations. Stockholm: Stockholms universitet. 


\section{8 | HELENE CARLBÄCK}

Haavio-Mannila, Elina \& Anna Rotkirch (2010) "Sexuality and Family Formation» i Stefan Immerfall \& Göran Therborn (red.) Handbook of European Societies. New York: Springer (465-497).

Hobsbawm, Eric J (2003) Ytterligheternas tidsålder: Det korta 1900-talet: 1914-1991. Översättning av Lena Lundgren, fackgranskning av Göran Andolf \& AlfW Johansson. Stockholm: ePan.

Hoffmann, David L. (red.) (2003) Stalinism: The Essential Readings. Malden: Blackwell Publishing.

Hoikkala, Tommi (1998) »Aljosha and Tapio. Two Cases of Compared fathering». Young 6 (3): 19-32.

Isupova, Olga \& Igor Kon (2009) "Materinstvo i otsovtsvo: Sotsiologitjeskij otjerk» i Irina Tartakovskaja (red.) Gender dlja tjainikov II. Moskva: Zvenia (114-135).

Johansson, Thomas (1998) »Pappor och deras pappor» i Claes Ekenstam (red.) Rädd att falla. Studier i manlighet. Stockholm: Gidlund.

Karpova, N. L. (red.) (2017) Ottepel. Moskva: Gosudarstvennaja Tretjakovskaja Galereja.

King, Laura (2015) Family Men: Fatherhood and Masculinity in Britain, 1914-1960. Oxford: Oxford University Press.

Kukhterin, Sergei (2000) "Fathers and Patriarchs in Communist and Post-Communist Russia» i Sarah Ashwin (red.) Gender, State and Society in Soviet and Post-Soviet Russia. London: Routledge (71-89).

Lapidus, Gail (1978) Women in Soviet Society: Equality, Development and Social Change. Berkeley: University of California Press.

Laslett, Peter (1983) „Family and Household as Work Group and Kin Group: Areas of Traditional Europe Compared» i Richard Wall, Jean Robin \& Peter Laslett (red.) Family Forms in Historic Europe. Cambridge: Cambridge University Press (513-563).

Lebina, Natalia (2017) Musjtjina i zjensjtjina. Telo, moda, kultura. SSSR - Ottepel. Moskva: Novoe literaturnoe obozrenie.

Liljeström, Marianne (1995) Emanciperade till underordning. Det sovjetiska könssystemets uppkomst och diskursiva reproduktion. Diss. Åbo: Åbo akademis förlag.

Lorentzen, Jørgen \& Claes Ekenstam (red.) (2006) Män i Norden: manlighet och modernitet 1840-1940. Möklinta: Gidlund.

Matt, Susan J. (2011) „Current Emotion Research in History: Or Doing History from the Inside Out». Emotion Review 3 (1): 117-124.

McDowell, Jennifer (1974) "Soviet Civil Ceremonies». Fournal for the Scientific Study of Religion 13 (3): $265-279$.

Mesjtjerkina, Elena (1996) "Institutsionalnyj seksizm i stereotypy maskulinnosti» i M. Malysjeva (red.) Demografija $i$ sotsiologija 15. Moskva: IESPN (196-206).

Municio-Larsson, Ingegerd (2012) "Doing Parenting in Post-Socialist Estonia and Latvia» i Helene Carlbäck, Yulia Gradskova \& Zhanna Kravchenko (red.) And They Lived Happily Ever After: Norms and Everyday Practices of Family and Parenthood in Russia and Eastern Europe. Budapest: CEU Press (273-295).

Nakachi, Mie (2006) "N. S. Khrushchev and the 1944 Soviet Family Law: Politics, Reproduction, and Language». East European Politics and Societies 20 (1): 40-68.

Reid, Susan (2004) "Women in the Home» i Melanie Ilic, Susan Reid \& Lynne Attwood (red.) Women in the Khrushchev Era. New York: Palgrave MacMillan (149-176).

Robinson, John P., Philip E. Converse \& Alexander Szalai (1972) »Everyday Life in Twelve Countries» i Alexander Szalai \& Philip E. Converse (red.) The Use of Time: Daily Activities of Urban and Suburban Populations in Twelve Countries. Haag: Mouton (113-144).

Rodin, Johnny \& Pelle Åberg (2014) "Fatherhood Across Space and Time. Russia in Perspective». Baltic Worlds: Scholarly fournal. News Magazine IV. http://balticworlds.com/across-space-and-time/?s=Fatherhood Across Space and Time. Läst 3 mars 2017.

Rotkirch, Anna (2000) The Man Question: Loves and Lives in Late 20th Century Russia. Helsinki: Väitösk. Helsingin yliopisto.

Rotkirch, Anna (2008) „Rakare, friare, friskare. Kollontajs vision för kvinnokroppen» i Yngvild Sørbye (red.) Revolusjon, kjarlighet, diplomati: Aleksandra Kollontaj og Norden. Oslo: Unipub (83-104).

Shlapentokh, Vladimir (1989) Public and Private Life of the Soviet People: Changing Values in Post-Stalin Russia. Oxford: Oxford University Press.

Schlesinger, Rudolf (1949) The Family in the USSR: Documents and Readings. London: Routledge and Kegan Paul Ltd.

Snegireva, Tatjana \& Aleksej Podtjinenov (2004) "Syn za otsa ne otvetjaet? kompleks bezotsovshchiny v sovjetskoj literature» i Sergej Usjakin (red.) Semejnye uzy-Modeli dlia sborki, kniga 2. Moskva: NLO (83-102).

Stearns, Peter (2008) "History of Emotions. Issues of Change and Impact» i Michael Lewis, Jeanette M. HavilandJones \& Lisa Feldman Barret (red.) Handbook on Emotions, 3rd ed. New York: The Guilford Press (17-31). 
Stearns, Peter (1979) Be a Man!: Males in Modern Society. New York: Holmes \& Meier.

Stiazhkina, Elena (2012) "The 'Petty-Bourgeois Woman' and the 'Soulless Philistine'. Gendered Aspects of the History of Soviet Everyday Life from the Mid-1960s to the Mid-1980s». Russian Studies in History 51 (2): 63-97.

Wagner, William G (1994) Marriage, Property, and the Law in Late Imperial Russia. Oxford: Clarendon Press.

Zdravomyslova, Elena \& Anna Temkina (2013) "The Crisis of Masculinity in Late Soviet Discourse». Russian Social Science Review 54 (1): 40-61.

Zhidkova, Elena (2012) „Family, Divorce, and Comrades’ Courts: Soviet Family and Public Organizations during the Thaw» i Helene Carlbäck, Yulia Gradskova \& Zhanna Kravchenko (red.) And They Lived Happily Ever After: Norms and Everyday Practices of Family and Parenthood in Russia and Eastern Europe. Budapest: CEU Press (47-64).

Zubkova, Elena (1998) Russia after the War: Hopes, Illusions, and Disappointments, 1945-1957. Armonk: M.E. Sharpe.

Zuzanek, Jiri (1980) Work and Leisure in the Soviet Union: A Time-budget Analysis. New York: Praeger.

\section{Forskningsmaterial}

Semja i sjkola: Zjurnal dlja roditielej. Moskva: Pedagogika, 1960-1989

\section{Förteckning över informanter}

AI, 58, gift med samma kvinna i 36 år, tre döttrar födda 1980-91 (intervju Carlbäck \& Ivanova 2016)

AL, 60, gift tre gånger, dotter född 1984, två söner född 2007 och 2013 (intervju Carlbäck \& Ivanova 2016)

GD, 75, gift med samma kvinna i 52 år, dotter född 1964 (intervju Carlbäck \& Ivanova, 2015)

MG, 75, gift med samma kvinna i 49 år, son född 1969, dotter född 1972 (intervju Carlbäck \& Ivanova 2015)

MP, 52, två döttrar födda 1988 and in 1991, gift med samma kvinna i 29 år, (intervju Carlbäck \& Ivanova 2015)

NA, 50, gift med samma kvinna i 30 år, dotter född 1989, son född 1995 (intervju Carlbäck \& Ivanova 2016)

OP, 81, gift med samma kvinna i 58 år, dotter född 1960 (intervju Carlbäck \& Ivanova, 2015)

PA, 75, gift med samma kvinna i 54 år, två söner födda 1963 och 1969 (intervju Carlbäck \& Ivanova, 2015)

PO, 62, gift två gånger, två döttrar födda 1978 och 1988 (intervju Ivanova 2015)

RA, 50, gift med samma kvinna i 29 år, dotter född 1984, (intervju Carlbäck \& Ivanova 2016)

VP, 53, gift med samma kvinna i 32 år, dotter född 1982 (intervju Ivanova 2016)

VS, 41, intervjuad om sin föräldra- och morföräldrageneration (intervju i Helsingfors Carlbäck 2015) 